\title{
Dynamics of Managerial Discretion in Transition Economies
}

\author{
Yuliya Ponomareva \\ School of Business \& Economics, Linnaeus University
}

\begin{abstract}
This conceptual paper is focusing on the dynamic nature of managerial discretion within the context of economic transition. The concept of managerial discretion is discussed in two diverse streams of literature. From the perspective of strategic management research, managerial discretion refers to the locus of managerial control, while the corporate governance research emphasizes control over corporation focusing on minimizing the discretionary power of the management team. This research attempts to highlight the complementarity of the two diverging perspectives. The paradox between managerial decision-making freedom and control is analyzed using example of economic transition. It is being argued that the presence of a dynamic institutional change characterizing the early stages of economic transition may assume the presence of higher degree of managerial freedom while the later stages of economic transition require more formalized mechanisms of control thereby limiting the degree of management discretionary power. As the level of environmental uncertainly is gradually decreasing during the process of economic transition the as institutional environment becomes more stable which, in turn, can lead to the establishment and formalization of control mechanisms. The methodological approach utilized in this study is a conceptual analysis of the previous research on managerial discretion applying institutional, corporate governance and strategic management research perspectives. A theoretical model uniting both corporate governance and strategic management perspectives on managerial discretion was developed. The institutional theory was applied to explain the complementarily of the two main perspectives, particularly within the context of institutional transition. Suggested directions for future research include empirical testing of changes in the level of the TMT discretion along the multiple stages of transition process and further development of interaction effects between different levels of the TMT discretion.
\end{abstract}

Keywords: Managerial discretion; top-management team (TMT); corporate governance; institutions; transition economies

\section{Introduction}

The question of a firm's adaptability constitutes one of the central topics of scientific debate within the field of management research. One stream of literature, in particular that concerned with strategic choice perspective, argues for the influence of top-management team (TMT) decisions on a firm's ability to adapt to the conditions of the external environment (e.g. Child, 1972; Wieserma and Bantel, 1992). On the other hand, the organizational ecology perspective asserts that organizations are influenced by the forces of their external environments and are unable to adapt. Consequently organizational success is solely dependent on the principle of 
"survival of the fittest" (e.g. DiMaggio and Powell, 1983; Hannan and Freeman, 1977). The concept of managerial discretion, which refers to the latitude of managerial actions, proposed by Hambrick and Finkelstein (1987), was created in an attempt to unite the two conflicting perspectives. Managerial discretion is viewed as a moderating variable that influences the process of organizational adaptation to the forces of its external environment (ibid).

The concept of discretion has received attention within two distinct fields of research: strategic management and corporate governance. The agency theory perspective views managerial discretion as a gray area where managers may maximize their own benefits at the expense of the shareholders' capital (Jensen and Meckling, 1976; Shleifer and Vishny, 1997). However, the majority of research on the agency theory examining the issue of managerial discretion tends to overlook the importance of situations in which the development of management is more important than the control over management (Shen, 2003). On the other hand, strategic management research views managerial discretion as the spectrum of opportunities for managers to achieve greater organizational adaptability to the firm's external environment.

The two contradictory perspectives present a duality of the conceptual understanding of discretion. It needs to be emphasized that the concept of discretion is neutral and is not correlated with an increased performance (Hambrick, 2007). This implies that both control over managers and managerial decision-making freedom are important aspects of a firm's strategic development. This paper attempts to overcome the one-sided view on managerial discretion by highlighting the duality of the concept through combining corporate governance as well as strategic management views on managerial discretion.

The theoretical debate between the proponents of the control approach and the advocates of the collaborative approach is far from being resolved within the field of management research (Westphal, 1999). One way to capture the nature of this duality is to apply a contingency perspective. A contingency perspective emphasizes the role of the external environment in shaping the degree of managerial discretion. Economic transition characterized by institutional uncertainty can be one example of contingent forces. This paper attempts to align the two divergent views on managerial discretion through examining the nature of forces that shape the degree of discretion at different stages of economic transition.

Previous research asserts that institutional settings affect the practices of corporate governance (Aguilera and Jackson, 2003) and the degree of discretion available to managers (Crossland and Hambrick, 2011). However, the under-socialized view on the corporation presented by the agency theory fails to take into consideration the institutional differences between different business environments (Aguilera and Jackson, 2010; Aoki, Jackson, and Miyajima, 2007). Most theoretical evidence on the subject of managerial discretion was developed and empirically tested within the context of stable institutional environments focusing primarily on differences in industrial sectors (Hambrick and Abrahamson, 1995). However, research focusing on distinct institutional settings is rather scarce (Crossland and Hambrick, 2011). To the knowledge of the author no studies have examined managerial discretion during the process of institutional change.

The newly emerging economies impose a considerable challenge to the scientific hegemony of the Western world, as they offer new approaches to management and strategic development. This presents an opportunity for researchers to test and develop the existing 
theory of managerial discretion by applying it in the context of distinct institutional settings of economic transition.

Transition economies represent a sub-group of countries within the category of emerging economies composed by countries that have become independent states following the collapse of the communist regimes (World Bank, 2002). The main characteristic defining transition economies is the presence of a distinct institutional environment (North, 1990) and its rapid change through the process of transition (Peng, 2000).

This group of countries presents an excellent case for highlighting the two perspectives on managerial discretion. During the process of economic transition, relationships between economic agents become more formalized (Peng, 2003), which implies greater opportunities for effective control over managerial actions. However, the early stages of transition, when informal institutions are prevalent, impose a high level of institutional and economic uncertainty due to the unpredictability of changes within the external environment. This, in turn, requires managers to react more quickly in order to ensure the firm's strategic adaptability as well as to come up with innovative solutions to newly emerging problems. In other words, the flexibility of a firm's strategy may require a greater amount of discretionary power for managers so that they can respond to new challenges in a timely manner.

The main contribution of this paper is the development of a conceptual framework capturing the dynamic nature of managerial discretion during the process of institutional change. This paper proposes that the duality of control and freedom perspectives on managerial discretion can be revealed by analyzing different stages of economic transition. In particular, it is argued that the presence of an institutional change characterizing the early stages of transition may assume the presence of a higher degree of managerial discretion. On the other hand, the later stages of economic transition characterized by formalized mechanisms of control may facilitate the decrease in discretion available to managers. These two views are reflected in the literature on managerial discretion within the fields of strategic management and corporate governance.

The paper is structured as follows: first, the strategy view on concept of managerial discretion is presented focusing on factors shaping the degree of managerial discretion at organizational and environmental levels. Subsequently, the corporate governance view on discretion is discussed highlighting the mechanisms that influence the degree of managerial discretion. Then the comprehensive model of factors influencing managerial discretion is presented, followed by the description of the process of economic transition and a discussion of managerial discretion within the context of economic transition. The last section presents conclusions, research implications and suggested directions for future research.

\section{Theory Development}

\section{Dimensions of managerial discretion}

Managerial discretion refers to the latitude of action that managers can undertake and largely applies to the analysis of top executives' actions within a corporation (Hambrick and Finkelstein, 1987). Decision-making can be virtually unlimited, albeit classifiable. The concept of managerial discretion is commonly classified into environmental, organizational, and individual levels of analysis (ibid). The majority of existing research on managerial discretion analyzes the concept at one level of analysis (Abrahamson and Hambrick, 1997; Carpenter and Golden, 1997). This approach may overlook the potential relationship between 
factors shaping managerial discretion at different levels. According to Hambrick and Finkelstein (1987), under restricted environmental conditions, environmental and organizational levels of managerial discretion increase in importance. Not underestimating the importance of each dimension of managerial discretion, the scope of this study will be limited to the two levels of managerial discretion: environmental and organizational.

\section{The environmental level of managerial discretion}

According to Hambrick and Finkelstein (1987), the environmental level of managerial discretion is determined by a number of factors derived from a firm's external environment. These factors include product differentiability, market growth, industry structure, demand instability, quasi-legal constraints, powerful outside forces, and capital intensity. It needs to be noted that each of the six factors can have a different direction of influence on managerial discretion. For example, greater demand instability is expected to decrease managerial discretion, while high market growth can expand the decision-making choices of a manager, thus having a positive influence on the degree of discretionary power. A study by Finkelstein and Boyd (1998) has verified the six factors originally proposed by Hambrick and Finkelstein (1987). A number of studies have also used these factors as proxies to capture the environmental managerial discretion at the environmental level of analysis (Abrahamson and Hambrick, 1997; Hambrick and Abrahamson, 1995).

A study conducted by Finkelstein and Hambrick (1990) assessed managerial discretion in different industries, revealing support for the proposed model of classifying industries into high-, moderate-, and low-discretion levels. The sub-factors that affect the degree of managerial discretion across industries include product differentiability, demand stability, capital intensity, competitive market structures, market growth, and freedom from government regulation (Finkelstein and Hambrick, 1990).

Researchers have only recently started to acknowledge the influence of institutions as an important factor influencing the nature of managerial discretion at the environmental level. A study by Crossland and Hambrick (2007) provides empirical support to the importance of a national governance system for the degree of managerial discretion. In addition to that, results show that the ownership concentration structure along with the corporate governance practices (e.g. CEO duality) may have a substantial effect on the degree of managerial discretion available to managers.

Later research by Crossland and Hambrick (2011) supported the assumption of the influence of institutional environment on the degree of managerial discretion. This may lead to the assumption that the degree of managerial discretion is a dynamic phenomenon. The process of institutional change may also result in change at different levels of discretion.

\section{Organizational level of managerial discretion}

According to Hambrick and Finkelstein (1987), the organizational-level determinants of managerial discretion include characteristics such as organization size, age, culture, and capital intensity as well as factors including resource availability and powerful inside forces. Organizational inertia has been thoroughly discussed within the management research literature (Hannan and Freeman, 1977; 1984; Tushman and Romanelli, 1985). Such factors as organization size, age, culture, and capital intensity comprise the inertial forces within an organization that are perceived to have a decreasing effect on the scope of managerial 
decision making ( $\mathrm{Li}$ and Tang, 2010). Larger organizations are more inertial due to the existence of multiple hierarchical levels and bureaucracy. A study by Miller, Kets de Vries, and Toulouse (1982) indicated that the discretion of managers correlated more with organizational strategy in small firms than in large ones. This supports the proposition that managers have more decision-making freedom in the organizations that have fewer inertial forces. Another force of organizational inertia derives from organization age. Older organizations are more embedded in existing routines, thus limiting managers' decisionmaking choices. Capital intensity imposes less liquidity of assets, consequently limiting available funds and restraining managers' strategic planning for a company (Hannan and Freeman, 1977).

Resource availability constitutes another important factor influencing managerial decisionmaking power. The greater the resource availability, the more slack resources the manager has at his or her disposal, and the larger the scope of decision-making opportunities. The literature on organizational slack (Bourgeois, 1981; Chakravarthy, 1982) has shown that the more organizational slack an organization possesses, the more strategic options are available to managers.

\section{The influence of stakeholders}

The powerful forces within external and internal environments of organizations were not discussed in detail by Hambrick and Finkelstein (1987) in their seminal article. Applying the term "stakeholders" to explain the locus of managerial control within an organization can provide a more structured and defined approach. As powerful forces may come from inside or outside an organization, we can distinguish between internal and external stakeholders. Stakeholders can be broadly defined as "any group or individual who can affect or is affected by the achievement of the firm's objectives" (Freeman, 1984, p. 25). This article is based on the assumption that managerial discretion is dependent on the restrictive power of other stakeholders within or outside a corporation, such as the board of directors or controlling shareholders, informal networks or governmental authorities. It can also be possible that one group of stakeholders may represent both the internal and external forces of managerial discretion. One example of a stakeholder that combines both internal and external roles could be a representative of governmental authorities simultaneously serving as a member of the board of directors.

Recognizing the interests of multiple groups of stakeholders is important for managers in order to ensure sustainability of the company in the future. According to Geletkanycz and Hambrick (1997), seeking information from external referents helps managers to reduce the amount of uncertainty they face during the process of strategic decision-making. However, taking into consideration the range of managerial responsibilities and the time constraints on decision making, it would be rational for a manager to prioritize only demands of the stakeholders that may substantially influence organizational outcomes.

While stakeholders of a company comprise one influential source that may affect the degree of managerial discretion, the governance mechanisms may serve as another tool to discipline managerial behavior. The next section explores the corporate governance view on the concept of managerial discretion. 


\section{Corporate governance perspective on managerial discretion}

The corporate governance view on managerial discretion derives from the agency perspective research (Fama, 1980; Jensen and Meckling, 1976). As the separation between management and control represents the core principle of a corporation, control over managerial decisions comprises the main goal of corporate governance mechanisms (Fama and Jensen, 1983). From the standpoint of corporate governance research, managerial discretion refers to managerial behavior that lies outside the mechanisms of control of a corporation (Vishny, 1997). Bearing in mind that the very purpose of mechanisms of corporate governance is to ensure that managerial actions are focused solely on maximizing the interests of the firm's stakeholders (Collin, 2006), it can be assumed that the strength of the governance mechanisms may have a negative influence on the degree of managerial discretion within a corporation.

The mechanisms of corporate governance can be classified into two main categories: internal and external. The internal mechanisms of control include supervision by the board of directors and the CEO compensation structure. The board of directors presents one control mechanism to limit the agency conflict between a company's management and its affiliated stakeholders. According to Fama (1980), the board of directors represents an institution responsible for monitoring the set contracts representing a firm. The market for managerial labor is another mechanism directed to ensure the maximization of the stakeholders' value. A manager who is no longer performing well will be replaced by better candidates for the position. In addition, information about the manager's performance will spread quickly on the market, making it difficult for him or her to find employment in the future.

According to Aguilera and Jackson (2003), the institutional mechanisms of corporate governance involve a property rights structure, a financial system, and inter-firm networks. As an example, a concentrated ownership structure can serve as a mechanism to strengthen the dominant shareholders' control over a corporation, thus limiting the degree of managerial decision-making freedom (Shleifer and Vishny, 1997). While top-management's affiliations with the powerful stakeholder groups may have their benefits in terms of resource provision and information access, strong collaboration between the two parties may also have a negative effect on the degree of managerial discretion. Another mechanism of managerial control can be strict financial audit requirements (Watts and Zimmerman, 1983). Imposing greater financial transparency can significantly limit the use of slack resources by the management team.

The summary of the factors influencing the degree of managerial discretion at the environmental and organizational levels is depicted in the model below. 
Figure 1: Factors influencing managerial discretion.

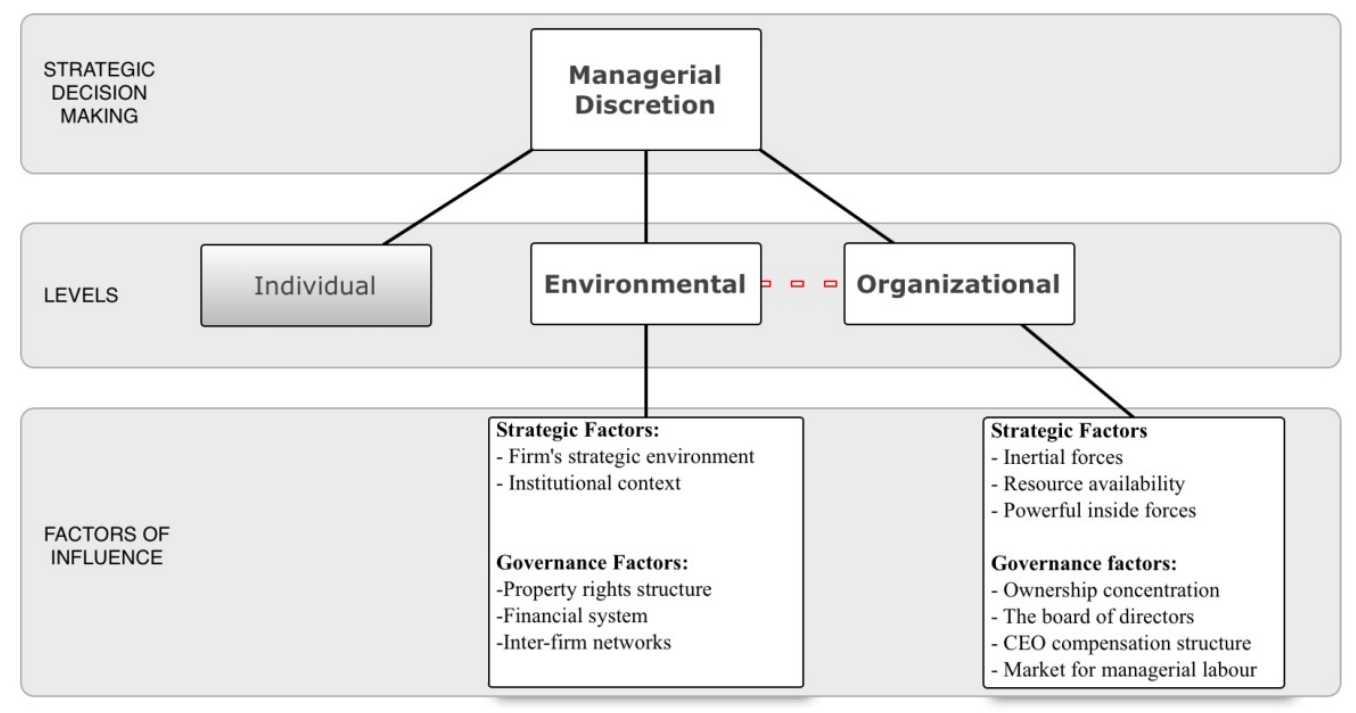

\section{Economic transition}

Transition economies, characterized by high levels of uncertainty (Puffer, McCarthy and Boisot, 2010) and the process of turbulent change (Zhuplev and Shein, 2008), can offer excellent opportunities to analyze different levels of managerial discretion and their change across the process of economic transition. The unpredictability of the consequences of reforms and institutional changes creates an uncertainty that managers have to accommodate. The presence of institutional voids leads to the creation of substitutes for them with informal institutions such as personal relationships and informal arms length contacts. However, along the process of transition the institutional environment becomes more stable, which, in turn, reduces the level of uncertainty and eventually leads to more interpersonal and formalized contacts between economic agents (Peng, 2003).

Environmental turbulence can be defined as “...volatility or difficult-to-predict discontinuities in an environment" (Haleblian and Finkelstein, 1993, p. 845). In the context of less predictable external environmental conditions, managers are forced to process larger amounts of new information at a fast pace (Galbraith, 1973). This leads to higher demands on information sharing and processing within a corporation (ibid).

The institutional theory helps to define the context of the turbulent environment of transition economies by explaining the coexistence of newly evolving institutions together with the legacy of the former institutional system that plays an important role in the economy (Peng, 2003).

In his study, Peng (2003) proposed a model of transition based on the assumption that the complexity of transactions increases during the process of transition. In his model Peng divides transition into two phases. The first phase is characterized by the dominance of relationship-based transactions. As time goes by, the market grows in size and the barriers to market entry become lower, leading to an increased number of transactions. As a result, companies are forced to operate with unfamiliar partners, gradually moving towards increased use of rule-based transaction mechanisms and therefore entering the second phase of the transition process. According to North (1990), the dominance of a rule-based, impersonal 
exchange model is the key distinguishing characteristic of a market economy. Yet it is important to note that the two types of exchange mechanisms are not mutually exclusive and they continue to be present in advanced economies.

\section{Managerial discretion during economic transition}

According to Hannan and Freeman (1977), organizations may require a wider variety of resources when operating in turbulent environments. Dominant groups of stakeholders can serve as resource providers for the company. In support of this, Wright, Filatotchev, Buck, and Bishop (2003) characterized transition economies as stakeholder-oriented economies, where business is influenced by groups of stakeholders such as the state, large FIGs, informal networks, and other important power players within an organization.

Taking into consideration the large amounts of information managers need to process within the context of uncertain environments, the stakeholders of a company may allow managers greater discretion in order to ensure organizational survival in the market. Through the interpersonal trust between stakeholders and managers, stronger links than those in formal relationships are created, thereby creating a relative certainty. In addition, collaboration and participation in making the firm's strategic decisions allows stakeholders to exercise participative control as well as to contribute to the firm's strategic development. Poorly functioning legal institutions inhibit the strength of the formal governance mechanisms (McNulty and Harper, 2012). A concentrated ownership structure characterizing countries with poor shareholder protection mechanisms (Vishny, 1997) can give impetus towards collaborative behavior between the managers and influential stakeholders. One can assume that a close collaboration can also be considered an informal control mechanism that protects stakeholders' interests.

In support to this, a study by Berman, Phillips, and Wicks (2005, B3) developed a theoretical argument that in the context of environmental uncertainty the importance of the stakeholders of a corporation will increase. The authors emphasized that both stakeholders and management can create more favorable outcomes from close collaboration than they would achieve if they were acting independently, basing their actions solely on self-interest. This leads to the assumption that the process of economic transition may influence the degree of managerial discretion at both the environmental and organizational levels.

The analysis of managerial discretion in the early stages of transition may call into question the relevance of the agency perspective within the context of an unstable institutional environment. The stakeholder theory emphasizes the role of multiple stakeholders in the organizational decisions-making process (Freeman, 1984). According to this approach, the managers are seen as coordinating agents managing the relationships between the firm and its multiple stakeholders. Applying this to the context of environmental uncertainty, collaboration with stakeholders allows managers gain an access to larger spectrum of valuable resources. This, in turn, may facilitate quicker strategic responses from the managers.

On the other hand, during the process of economic transition the institutional environment becomes more stable and therefore more predictable. Improved legislative system and stronger law enforcement lead to an increasing importance and applicability of formal mechanisms of control. The owners of capital may rely more heavily on formal protection, thus limiting their informal control over a firm. The strategic environment of a firm is also expected to stabilize gradually, this, in turn, can decrease the number of strategic 
opportunities due to more established "rules of the game". On the other hand, due to the increasing predictability of external environment managers may require less information in order to undertake strategic decisions, which will increase strategic flexibility of a firm. The influence of stakeholders is assumed to become less vital for the firm's survival on the market. Thus managers may increase their discretion due to more developed markets with less impact of quail-legal constraints, increased market competition and product differentiation.

To conclude, the agency theory explanation of the relationship between the top-management team and shareholders of a company may be more applicable to the later stages of the economic transition process, whereas the stakeholder theory bears greater explanatory power at the early stages of transition process. It is also important to note the nature and influence of factors that shape managerial discretion may change through the process of economic transition. In particular, the increased power of formal institutions is assumed to have a positive influence on the strength of governance incitements, thus limiting the degree of discretion available to managers.

\section{Conclusions}

This study presents a theoretical framework drawing upon the corporate governance and strategy perspectives on managerial discretion. More specifically, it combines the stakeholder and agency theories in the analysis of managerial discretion within the context of institutional change. This paper contributes to the present literature on managerial discretion through (1) highlighting the duality of perspectives on managerial discretion (2) applying the concept of managerial discretion to the context of a distinct institutional environment of transition (3) showing the dynamic nature of managerial discretion through different stages of transition process.

The results of the study are in line with the emerging research on the influence of institutional environments on the degree of managerial discretion (Crossland and Hambrick 2007; 2011). The analysis of discretion during the process of institutional change reveals how the applicability of the two approaches to discretion changes during transition. More specifically, it is argued that under conditions of environmental instability the TMT may coordinate the interests of dominant stakeholders more intensively in order to adapt a company to external conditions and, thus, the stakeholder theory becomes a more appropriate explanation of the TMT-stakeholders relationship. On the other hand, the formalized nature of economic transactions characterizing the later stages of economic transition may allow stakeholders to rely on formal mechanisms of control of the corporation. This leads to the assumption that the agency perspective, which focuses on the control between the agents and principles of the corporation, becomes more applicable in explaining the TMT-stakeholders relationship.

In an attempt to overcome the limitations associated with the use of a single theory, this study synthesizes several theories, including the agency, stakeholder, and institutional theories, in order to explain the nature of managerial discretion within the context of economic transition. The wider scope of a multi-theoretical approach may serve as an instrument to create theories that are applicable to the distinct institutional environments. Suggested directions for future research include empirical testing of changes in the degree of TMT discretion along the multiple stages of the transition process and further development of interaction effects between different levels of TMT discretion. 


\section{References}

Abrahamson, E. and Hambrick, D.C. 1997. Attentional homogeneity in industries: The effect of discretion, Journal of Organizational Behaviour, vol. 18, pp. 513-532.

Aguilera, R. and Jackson, G., (2010), "Comparative and international corporate governance," Academy of Management Annals, vol. 4, no. 2, pp. 485-556.

Aguilera, R. and Jackson, G., (2003), "The cross-national diversity of corporate governance: Dimensions and determinants," Academy of Management Review, vol. 28, no. 3, pp. 447-485.

Aoki, M., Jackson, G., and Miyajima, H., (2007), Corporate Governance in Japan: Institutional Change and Organizational Diversity, Oxford: Oxford University Press.

Berman, S., Phillips, R.A. and Wicks, A., (2005), Resource dependence, managerial discretion and stakeholder performance, Proceedings of the Academy of Management.

Bourgeois, L.J., (1981), “On the measurement of organizational slack," Academy of Management Review, vol. 6, pp. 29-39.

Carpenter, M.A. and Golden, B.R., (1997), "Perceived managerial discretion. A study of cause and effect," Strategic Management Journal, vol. 18, no. 3, pp. 187-206.

Chakravarthy, B.S., (1982), "Adaptation: A promising metaphor for strategic management," Academy of Management Review, vol. 7, pp. 35-44.

Child, J., (1972), "Organizational structure environment and performance: The role of strategic choice," Sociology, vol. 6, pp. 1-22.

Collin, S.-O., (2006), The Mastering of the Corporation: An Integrated View on Corporate Governance, Lund University.

Crossland C. and Hambrick, D.C., (2007), "How national systems differ in their constraints on corporate executives: A study of CEO effects in three countries," Strategic Management Journal, vol. 28, no. 8, pp. 767-789.

Crossland, C. and Hambrick, D.C., (2011), "Differences in managerial discretion across countries: How national-level institutions affect the degree to which CEOs matter," Strategic Management Journal, vol. 32, pp. 797-819.

DiMaggio, P. and Powell, W., (1983), "The iron cage revisited: Institutional isomorphism and collective rationality in organizational fields," American Sociological Review, vol. 48, pp. 147-160.

Fama, E., (1980), "Agency problems and the theory of the firm," Journal of Political Economy, vol. 88, no. 2, pp. 288-307.

Fama, E. and Jensen, M., (1983), "Separation of ownership and control," Journal of Law and Economics, vol. 26, pp. 301-325. 
Finkelstein, S. and, Boyd B.K., (1998), How much does the CEO matter? The role of managerial discretion in the setting of CEO compensation. The Academy of Management Journal, 41(2), pp. 179-199.

Finkelstein, S. and Hambrick, D., (1990), “Top-management-team tenure and organizational outcomes: The moderating role of managerial discretion," Administrative Science Quarterly, vol. 35, no. 3, pp. 484-503.

Freeman, R.E., (1984), Strategic Management: A Stakeholder Approach, Pitman, Boston.

Galbraith, J., (1973), Designing Complex Organizations, Addison-Wesley, Boston.

Geletkanycz, M.A., and Hambrick D.C., (1997), "The external ties of top-executives: Implications for strategic choice and performance," Administrative Science Quarterly, vol. 42, no. 4, pp. 654-681.

Haleblian, J. and Finkelstein, S., (1993), "Top management team size, CEO dominance, and firm performance: The moderating roles of environmental turbulence and discretion," The Academy of Management Journal, vol. 36, no. 4, pp. 844-863.

Hambrick, D.C., (2007), "Upper echelons theory: An update," Academy of Management review, vol. 32, no. 2, pp. 334-343.

Hambrick, D.C. and Abrahamson, E., (1995), "Assessing managerial discretion across industries: A multimethod approach," Academy of Management Journal, vol. 38, no. 5, pp. 1427-1441.

Hambrick, D.C. and Finkelstein, S., (1987), "Managerial discretion: A bridge between polar views of organizational outcomes," Research in Organizational Behavior, vol. 9, pp. 369-406.

Hannan, M.T. and Freeman, J.H., (1977), "The population ecology of organizations," American Journal of Sociology, vol. 82, pp. 929-964.

Hannan, M.T. and Freeman, J.H., (1984), "Structural inertia and organizational change," American Sociological Review, vol. 49, pp. 149-164.

Jensen, M.C. and Meckling, W.H., (1976), "Theory of the firm: Managerial behaviour, agency costs and ownership structure," Journal of Financial Economics, vol. 3, no. 4, pp. 305-360.

Keefer, P. and Knack, S., (2005), "Social capital, social norms, and the new institutional economics," in Menard, C. and Shirley, M.M, (Eds.), Handbook of New Institutional Economics,. Springer: New York, pp. 701-725.

Li, J. and Tang, Y., (2010), "CEO hubris and firm risk-taking in China: The moderating role of managerial discretion," Academy of Management Journal, vol. 53, no. 1, pp. 45-68. 
McNulty, J.E. and Harper J.T. (2012), Obstacles to financial development in transition economies: A literature survey, Financial markets, Institutions and Instruments: Topics in Financial Intermediation, New York University Salomon Center.

Miller, D., Kets de Vries, M. and Toulouse, J., (1982), "Top executive locus of control and its relationship to strategy-making, structure, and environment," Academy of Management Journal, vol. 25, pp. 237-253.

North, D., (1990), Institutions, Institutional Change and Economic Performance, Cambridge: Cambridge University Press.

Peng, M.W., (2000), Business Strategies in Transitional Economies, Sage, Thousand Oaks, CA.

Peng, M.W., (2003), "Institutional transition and strategic choices," Academy of Management Review, vol. 28, no. 2, pp. 275-296.

Puffer, S.M., McCarthy, D.J., Boisot, M., (2010), "Entrepreneurship in Russia and China: The impact of formal institutional voids," Entrepreneurship Theory and Practice, vol. 34, no. 3, pp. 441-467.

Shen, W., (2003), "The dynamics of CEO-board relationship: An evolutionary perspective," The Academy of Management Review, vol. 28, no. 3, pp. 466-476.

Shleifer, A. and Vishny, R.W.A., (1997), “A survey of corporate governance,” The Journal of Finance, vol. 52, no. 2, pp. 737-783.

Tommaso, M.L.D., Raiser, M. and Weeks, M., (2007), "Home grown or imported? Initial conditions, external anchors and the determinants of institutional reform in the transition economies," The Economic Journal, vol. 117, pp. 858-881.

Tushman, M.L. and Romanelli, E., (1985), "Organization evolution: A metamorphosis model of convergence and reorientation," in L.L. Cummings and Staw, B. M., (Eds.), Research in Organizational Behaviour, vol. 7: pp. 171-222, Greenwich, CT. JAI press.

Watts R., L., and Zimmerman, J., L., (1983), "Agency Problems, Auditing and the theory of the Firm: Some evidence", Journal of Law and Economics, vol. 26, pp. 613-633

Westphal, J.D., (1999), "Collaboration in the boardroom: The consequences of social ties in the CEO/board relationship,” Academy of Management Journal, vol. 42, pp. 7-24.

Wieserma, M.F., \& Bantel, K. A. (1992). Top management team demography and corporate strategic change. Academy of Management Journal, 35, 91-122.

World Bank, (2002), World Development Report: Building Institutions for Markets, Washington: World Bank. 
Wright, M., Filatotchev, I., Buck, T. and Bishop, K., (2003), "Is stakeholder corporate governance appropriate in Russia?" Journal of Management and Governance, vol. 7, pp. 263-290.

Zhuplev, A. and Shein, V.I. (2008), "Russia's evolving corporate governance within the cultural context," Journal of Transnational Management, vol. 10, no. 3, pp. 19-38. 